\title{
A New Manuscript of Joachim Meyer (1561)
}

\author{
Olivier Dupuis, \\ Independent researcher
}

\begin{abstract}
The manuscript of Joachim Meyer, dated to 1561 and kept in the Bavarian National Museum in Munich, was ignored by specialised bibliographical works on fencing and was absent in the secondary literature about fight books. Its re-discovery sheds a new light on the story of the composition of the treatise printed by this same author in 1570 . This research note briefly presents the manuscript and the perspectives it opens up, pending a larger scientific investigation. It contains a description of the manuscript and its contents, as well as new findings regarding biographical information about the author.
\end{abstract}

Keywords - Joachim Meyer, manuscript, fight book, rediscovery

\section{INTRODUCTION}

\section{I.1. State of knowledge before the rediscovery of the manuscript}

The earliest mention of the manuscript appears in a fight book by Wilhelm Lübeck, printed in 1865, where, in a chapter about historical perspectives on the art of combat, he mentions the existence of a manuscript by Meyer from 1561, and in particular an illustration which astonishes him. This illustration depicts a sword whose crosspiece is in the shape of a weapon of war and whose pommel is a morning star. ${ }^{1}$ He is most certainly

Acknowledgement: In 2005, I was contacted by Mike Cartier, through Matt Galas, to invite me to search the Strasbourg archives for traces of Joachim Meyer. The author of the Gründtliche Beschreibung der Kunst des Fechtens, published in Strasbourg in 1570, was not unknown to me at the time, but I did not expect to find so much biographical material, let alone to become so attached to this archival work so that I have not spent a year since without visiting one or other of the archives. Two undated manuscripts by Joachim Meyer were located between 2008 and 2009, the first in the university library in Lund, the second in the library in Rostock (The Lund library has curiously registered the manuscript under the name of the print, Gründtliche Beschreibung des Fechtens, the Rostock library has registered its manuscript under Mss. var. 82). In around 2011, a few researchers quickly identified the existence of a third manuscript by Joachim Meyer, also dealing exclusively with fencing, kept in the Bavarian National Museum in Munich at the end of the nineteenth century, dated precisely to 1561 . This research work led to the publication of a blog post wrongly concluding that it had disappeared (Kleinau, '1561 Joachim Meyer dedicated a fencing book to the Pfalzgrafen of Pfalz-Veldenz'. The rediscovery, however, would not have been possible without this preliminary research and publication). The manuscript has in fact never left the museum and is currently kept there with the shelf mark Bibl. 2465. I dedicate this short research note to Mike Cartier, who left us a few years ago and would have been excited beyond reason by this discovery. 
referring to the Munich manuscript - in particular to one of the three illustrations of combat in armour found on fols 109v $111^{\mathrm{v}}$, and $112^{\mathrm{v}}$ of the manuscript, all three of which show armoured combatants holding specific swords designed for armoured fighting on foot (with an axe blade instead of the quillons, a handle in the middle of the blade, and additional spikes mounted on the pommel). Lübeck does not say where he was able to consult the manuscript, which would have been interesting.

The Munich State Museum (today Bayerisches Nationalmuseum) did not open its doors until 1868, and in that year it published a catalogue which mentioned the presence of Meyer's manuscript in the following terms:

On a small table lies a very valuable manuscript with a pretty, polychromic original leather binding. This is the fencing book by Joachim Meyer 1561, dedicated to Görg Hansen Count Palatine near the Rhine, with illuminated original hand drawings of sword fencing, dagger fencing, polearms fencing, and fighting in armour, etc. ${ }^{2}$

The manuscript appears to have been on continuous display until the museum moved in the 1900s. In fact, its last mention in museum catalogues occurs in $1887 .{ }^{3}$ It has received little publicity apart from the publication of an illustration in a curious book by HefnerAlteneck that mixes costume, craft, and artworks. Plate 489 is attributed to Joachim Meyer's 1561 manuscript but indicates a dedication to Johan Georg Count Palatine, not Georg Hans, as stated in the museum catalogue. The note associated with this plate also indicates that the manuscript has 87 drawings, yet the Munich manuscript contains only 79 , and to make matters worse, the illustration on plate 489 (fig. 2) does not match any of those. Rather, it seems to have been recomposed for this publication from the illustration on fol. 50 $0^{\mathrm{r}}$ of the manuscript Opus Amplissimum de Arte Atheltica attributed to Paulus Hector Mair in the Bavarian State Library (fig. 1). ${ }^{4}$ It would therefore seem to be an understandable confusion for a public outreach work, between two manuscripts preserved in Munich, both associated with similarly named authors, Mair and Meyer, and whose misattribution was propagated until the middle of the twentieth century. ${ }^{5}$ No

${ }^{1}$ Lübeck, Lehr- und Handbuch, p. 6. Quoted in Kleinau, '1561 Joachim Meyer dedicated a fencing book to the Pfalzgrafen of Pfalz-Veldenz'.

${ }^{2}$ Das bayerische Nationalmuseum, p. 213. The history of the museum from its conception in 1855 to its move in 1890 is detailed in the book Fübrer durch das bayerische Nationalmusuem, pp. 5-26. It is also mentioned in the protocols of a meeting of the Alterthum-Verein in 1869 (Sitzungsberichte des Münchener Alterthums-Vereins, 1869). I thank Raphaël Beuing for providing me with this information.

3 Fübrer durch das Königlich bayerische national-museum in München, p. 116; Mayer, Katalog der Büchersammlung, p. 35.

4 Manuscript commissioned by Paulus Hector Mair, Cod. icon. 393 in the Bayerische Staatsbibliothek.

${ }^{5}$ Hefner-Alteneck, Trachten, Kunstwerke und Gerätschaften; Pylkkänen Säätyläispuku Suomessa, p. 417. 
further mention of the manuscript appears after the museum moved to its present location in 1900 (work on the building started in 1894, but was completed in 1900).

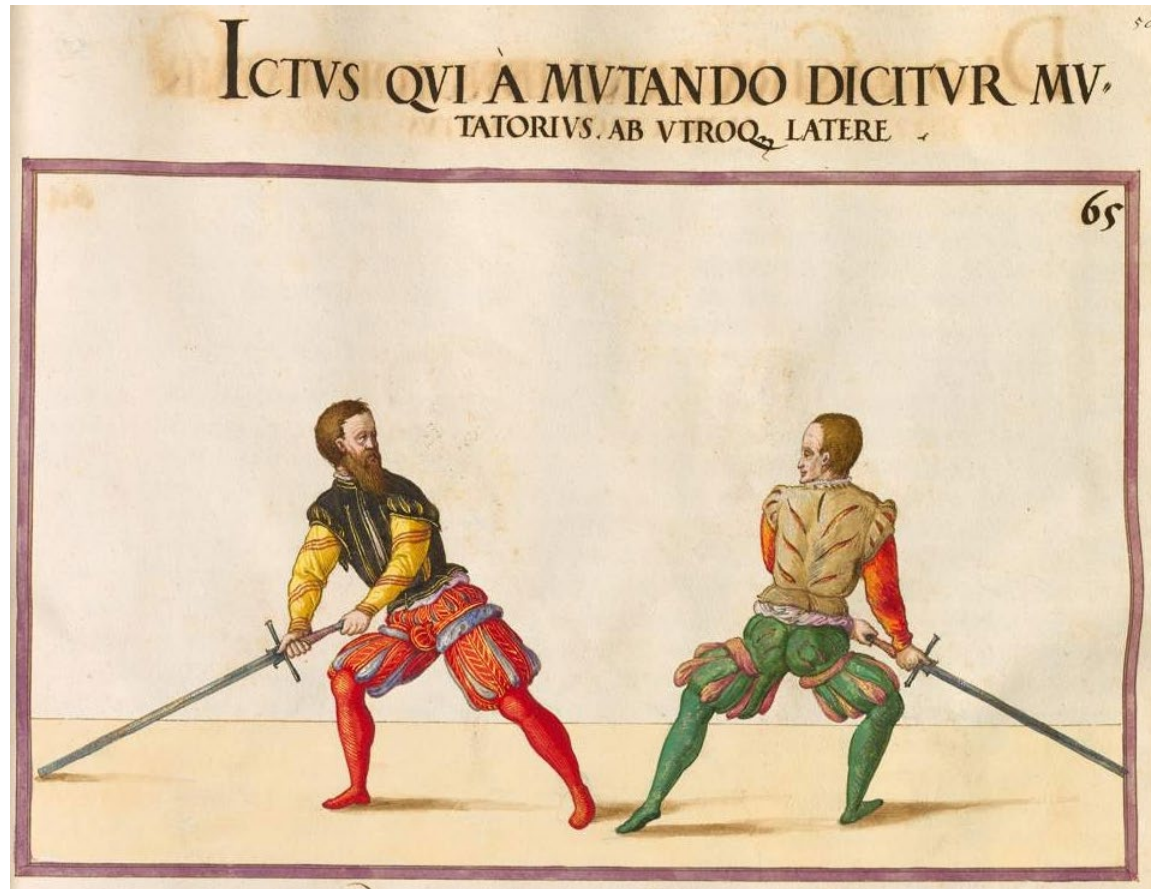

Figure 1: Paulus Hector Mair, Opus Amplissimum de Arte Atheltica, 1550 (Munich, Bayerische Staatsbibliothek, cod. Icon. 393, fol. 50r). Reproduced with permission.

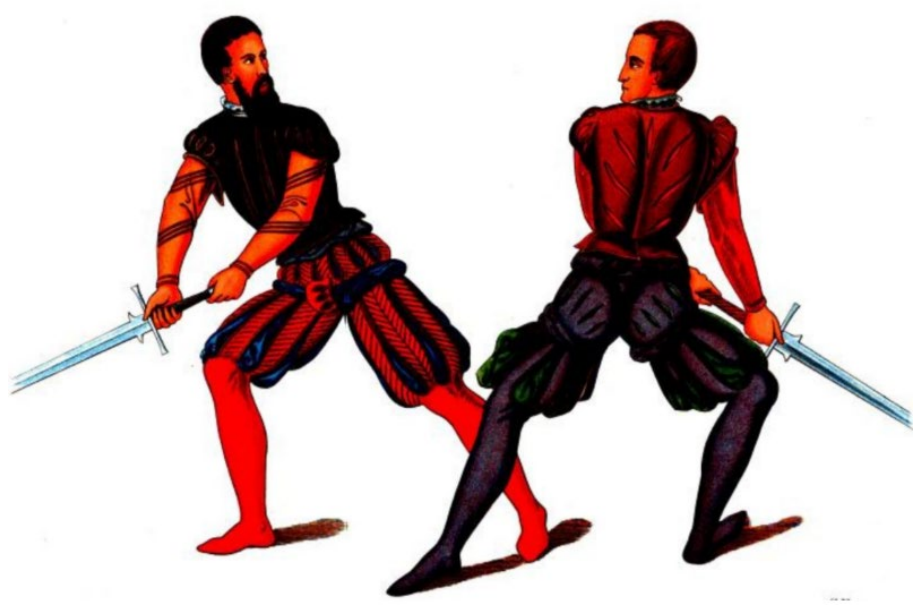

Figure 2: Hefner-Alteneck, Trachten, Kunstwerke und Gerätschaften, plate 489. 


\section{I.2. About the author Joachim Meyer}

Joachim Meyer became a citizen of Strasbourg in 1560 as a cutler through his marriage to a widow with burgher's rights. He indicates that he came from Basel, where he probably had the status of burgher, and he could have been born in 1537, but this is suggested without absolute certainty because there are homonyms of other men born at around the same time. At this stage of our knowledge, there is nothing to prevent us from imagining that Joachim Meyer was born elsewhere and acquired the status of burgher in Basel at some later date. Further studies are still needed in Basel to see whether these hypotheses can be verified, with the problem that the name Meyer is very common there. The improvement of indexing tools in the future should facilitate such work, and help to identify mentions that may have gone unnoticed until now, such as this document from November 1558. It shows that Joachim's presumed parents, Jakob Meyger and Anna Fründt, rented a house in the suburb of St. Alban, the parish where Joachim Meyer was baptised in 1537 , at a fairly high price and owned vineyards, indicating a fairly well-to-do social status. ${ }^{6}$

From 1560 to 1570 Joachim Meyer leaves little trace in the archives apart from organising public fencing demonstrations (Fechtschulen), and in 1570 he held the post of treasurer of the court of the Strasbourg smiths' guild (Schmidrunft), which proves that he had the status of master and not just a simple worker. Finally, in 1571, he left Strasbourg to enter the service of the Duke of Schwerin but died shortly after his arrival. ${ }^{7}$ In a letter addressed to the Duke on 24 February 1571, his death was confirmed by a chancellor who complained about the lack of a physician at the court who could have saved the master from illness. ${ }^{8}$

Meyer's professional activities remain enigmatic, because if we consider that he had the time not only to teach fencing but also to develop innovative thinking on the theory of fencing and to further develop it in various very neat treatises, all while holding the office of treasurer of a guild, then this does not support the idea of a master cutler in charge of a production workshop with the responsibility of supervising workers. Like most of the people in charge in the Strasbourg guilds, it would be more likely that he was mainly involved in the trade of bladed weapons, which was more compatible with the opportunity to free up time for other activities without too much impact on his standard of living.

${ }^{6}$ Basel Universitätsarchiv, K 7, fol. 107. Transcription of the document in appendix.

${ }^{7}$ For further details, see Dupuis, 'Joachim Meyer, free fencer, citizen of Strassburg'. This is a slightly updated version from the original article: Dupuis, Joachim Meyer, escrimeur libre, bourgeois de Strasbourg'.

${ }^{8}$ Merkel, Heinrich Husanus, p. 188. Information kindly provided by Kevin Maurer. The letter itself is in Latin, but the book of Merkel provided a short translated excerpt including this information. The original letter should be researched and would potentially provide more information about the death of the master. I had no time to do this within writing the scope of this research note. 
The discovery of this 1561 manuscript led me to return to the Strasbourg archives to try and find mentions of the presence of Georg Hans of Veldenz, but without success. However, this approach did enable me to identify two new mentions of Fechtschulen connected to Joachim Meyer, which I had not located before, dating from 1560 and 1563. ${ }^{9}$ Both consist of a request made to the town council to organise a Fechtschule with the aim of having one of Meyer's pupils become a master. I had already identified such a request dating from 1561. Over a period of four years, Joachim Meyer trained and prepared four fencers for the fencing master's examination; this must have required a far greater investment of time than giving private lessons to wealthy pupils. Generally speaking, the professional activities of the fencing masters in the Holy Roman Empire are still very unclear; the fact that the activity of the fencing master is not recognised as a profession in the institutional sense of the term blurs the picture of this activity considerably.

\section{I.3. The works of Joachim Meyer}

Joachim Meyer is, above all, the author of an important and famous treatise printed in Strasbourg in 1570 , which is accompanied by sumptuous plates attributed to Tobias Stimmer. This treatise was reprinted posthumously in Augsburg in 1600 with a rearrangement of all the pages, but using the same plates and without any significant changes in the text. ${ }^{10}$ Pierre-Alexandre Chaize sees in this work the beginnings of a burgher's sport that puts the body in movement through social activity, with the prospect of being able to put it at the service of the city. ${ }^{11}$ His analysis is very convincing, but obscures the attraction of the so-called bourgeoisie for an activity that remained strongly associated with the aristocrats, for whom the carrying of the sword was a form of profession. ${ }^{12}$ The aristocracy also retained a great interest in the art of combat and obliged themselves to master its techniques. Indeed, this treatise by Joachim Meyer is dedicated to Johann Casimir, Count Palatine and Duke of Bavaria, who belonged to a younger branch of the Palatine house of Wittelsbach, the Pfalz-Simmern. He is a contemporary of Georg Hans who, by a curious coincidence, has the same birth and death dates (15431592).

Joachim Meyer is also the author of another manuscript, dedicated to Otto von Solms and preserved in Lund, dated to approximately 1568, about the time when the young

\footnotetext{
9 See transcriptions in appendix.

${ }^{10} \mathrm{I}$ mentioned in my biographical article a reprint in 1660. In all likelihood, this is an error that has been repeated since at least the nineteenth century. It is simplest to assume that all surviving copies are from the 1570 and 1600 editions only, until proven otherwise.

11 Chaize, 'Les arts martiaux de l’Occident médiéval', pp. 535-45.

12 Brioist, Drévillon, and Serna, Croiser le fer, pp. 50-70.
} 
prince was in residence in Strasbourg. ${ }^{13}$ This manuscript combines text and pictures and, in many respects, including form and size, is very comparable to the Munich manuscript.

Meyer is also acknowledged as the author of the manuscript var. 82 in the University Library of Rostock. The object is a compilation of two manuscripts by various authors, including Meyer himself, collected by him in Strasbourg, without any indicated date. The first manuscript (fols $1^{\mathrm{r}-122 \mathrm{v}}$ ) is a large compilation of texts, under the title Fechtbuch von allerband geschwinden Stucken $₹ u$ Ross vnd zu fuss vnd zum kampf (fol. $5^{\mathrm{r}}$ ). The second is a small treatise on rapier fencing, entitled Fechten im Rapier zusamen gethragen aus dem italianischen spanischen neapolitanischen francöschen vnd theischen und worauf dess selbigen grund vnd rechte fundament stande. It is dedicated to Heinrich, Count of Eberst, and dated to 1570 (fols 123r$27 \mathrm{v})$. The Rostock document would require detailed study, especially codicology, to determine whether the date given in the small treatise can be applied to the whole or whether the first part is much earlier. In any case, it differs from the others in the absence of illustrations, apart from two diagrams in the very first folios, and in its format, which is taller than it is wide (when the other manuscripts are oblong).

\section{THE MANUSCRIPT OF THE NATIONAL MUSEUM OF BAVARIA (BAYERISCHES NATIONALMUSEUM)}

\section{II.1. The document}

Without further research it is difficult to trace the history of the manuscript. It seems possible, however, to identify three to four stages in its production. These include the making of the numerous illustrations, the writing of the different chapters, and the creation of accompanying text - which sometimes surrounds certain images - or a few words written along the shaft of large spikes. The text is written in at least two different hands. The internal numbering starts after the three pages of the dedication that introduces the manuscript; this introduction was probably made at the time of the physical constitution of the manuscript as it was transmitted to us, shortly before the binding stage. The binding, having imposed the calibration of the pages, led to several page numbers being cut off.

On fol. $2^{\mathrm{r}}$ to $3^{\mathrm{v}}$ is a dedication to Prince Georg Hans, Count Palatine, Duke of Bavaria and Count of Veldenz (1543-92), and opposite the first page on fol. $1^{\mathrm{v}}$ is the coat of arms of the Counts of Veldenz. In the address he is attributed with the much more obscure title of Lord of La Petite Pierre, 'Herr von Lützelstein', a small principality in the northern Vosges whose seat is the small fortified site of Lützelstein, less than $60 \mathrm{~km}$ north-west of Strasbourg. The biography of Georg Hans, until now, noted the transmission of the

\footnotetext{
13 This manuscript does not have a precise shelf mark in the university library, which seems to have confused several of my colleagues who continue to give it an old shelf mark, A $4^{\circ} 2$. For example, Forgeng, Joachim Meyer, The Art of Sword Combat: A 1568 German Treatise on Swordmanship.
} 
county associated with this place from his uncle only in around 1563, from when he seems to settle regularly in this place, and develop the territory until around 1570 . The dedication of our manuscript thus opens up a new perspective in the life of the young prince, who was only eighteen years old in 1561. It could be that before the official transmission of the title of Count of Lützelstein he had already obtained some of the privileges and powers and started to settle in this region, which he certainly took advantage of to visit Strasbourg. The end of the dedication gives the only indisputable element of dating: 1 March, 1561, according to the Julian calendar, thus 11 March according to our current Gregorian calendar.

This dedication does not necessarily lead to the conclusion that the manuscript was actually offered to this prince, even though it is highly probable. There is no tangible evidence of this, and in all the manuscript, apart from the marks of the Munich State Museum, there is only a curious signature written upside down on the first flyleaf (fol. $0^{\mathrm{r}}$ ), that of one Alexander Charles Maurice, who remains as of yet unidentified. The first mention of the manuscript remains the already mentioned fencing manual published in 1865. The second mention dates from 14 October, 1867, when it was presented by a local scholar, Reichsrath von Aretin, at a meeting of the Society of Antiquaries in Munich. It is possible that it was acquired after this presentation. ${ }^{14}$ The path of this manuscript from La Petite Pierre to the Munich Museum has yet to be researched.

\section{II.2. Description of the content}

The following information is provided solely on the basis of photographs provided by the museum, and without the manuscript having yet been physically consulted. It will be necessary to develop this description with further codicological study.

The manuscript consists of pages written in German, in a style characteristic of the second half of the sixteenth century. The text is accompanied by 79 illustrations, most of which are in bright colours and depict pairs of fencers. The format is similar to that of the Lund manuscript, $21.5 \times 30 \mathrm{~cm}$ (cover), and $20 \times 29 \mathrm{~cm}$ (page).

The binding is made of brown embossed leather that shows scrolls and geometric patterns, leaving two small heads as the only figurative elements. Some of the motifs show traces of white and red paint, suggesting that all the motifs were originally painted. Three small pastilles are recessed on the spine, and the location of a possible fourth is hidden by a label indicating the number 2465 , its shelf number in the museum library.

The manuscript consists of 120 pages, the first and last of which are flyleaves, probably added when the binding was made. It therefore seems more appropriate to count 118

\footnotetext{
14 Sitzungsberichte, p. 6. See also Weniger, 'Die Büchersammlung des Bayerischen Nationalmuseums', where the author refers to this presentation as the oldest mention of the manuscript. The act of purchase of the manuscript may be found, in the years following this presentation in 1869. Personal communication.
} 
folios. Most of the pages are numbered on the front, in the upper right-hand corner, with some rare exceptions which I will mention later. This numbering must correspond to a state prior to the constitution of the present manuscript, as several numbers were cut off when the pages were calibrated before they were bound. This numbering does not include the dedication and contains, in the present state of the manuscript, two anomalies. The first appears at the very end of the section on the rapier, where two pages (fols $70^{\mathrm{r}}-71^{\mathrm{v}}$ ) seem to have been added later and are inserted between numbers 66 and 67 . The second anomaly is located a little further on, between folios 80 (numbered 75) and 82 (numbered 79). Two numbered pages would therefore be missing between the preserved folios; it seems difficult to propose a hypothesis at this stage without the codicological study, in particular the state of the organisation of the quires. Finally, we should mention the repair of folio 12. In the opinion of Dr. Weiniger, curator of paintings at the museum, the repair seems to have been carried out at an early stage; the piece of paper glued to the page looks similar to what is otherwise observed in the manuscript.

The manuscript contains 79 illustrations, including the coat of arms associated with the dedication and a simple ink drawing of a sword. All other illustrations are in colour and sometimes, in the section on the large pike, run across the two open pages. The style of these illustrations differs from those in the Lund manuscript and are probably by another illustrator. Some of the colours remain extremely vivid and may have benefited from an intermediate restoration. The style of the clothing is very much of the sixteenth century, but with some unusual outrageousness, especially in the length of the puffed-up part of the trousers or in some of the braguettes.

Some of the compositions of the drawings in the rapier section are reminiscent of engravings in the influential Italian fight book of Achille Marozzo (Opera Nova, 1536), particularly the illustration on fol. $63^{\mathrm{v}}$ (figs 3 and 4), which features a floor diagram. ${ }^{15}$ This echoes Luis Pacheco de Narvaez's remark that Meyer's work was already assumed in the seventeenth century to be a German translation of Marozzo. ${ }^{16}$

\footnotetext{
15 I thank Thomas Rivière for this remark.

${ }^{16}$ Narvaèz, Nueva Ciencia. 'Achile Maroço [...] Lo mismo hizo su traductor Ioachim Meyer...', p. 490, 'Y este mismo premio se le deve à Iochin Meyer, por aver traducido en lengua Tudesca [Achille Marozzo] ..., p. 578.
} 


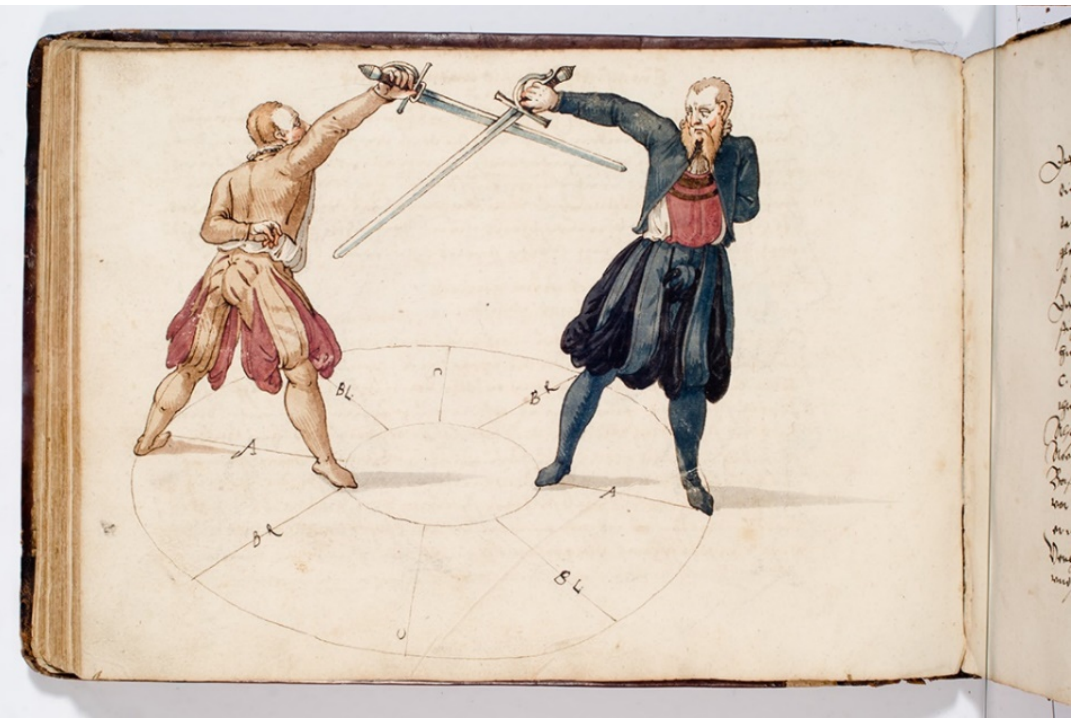

Figure 3: Joachim Meyer, [Fechtbuch], 1561 (Munich, Bayerisches Nationalmuseum, Bibl. 2465). Reproduced with permission.

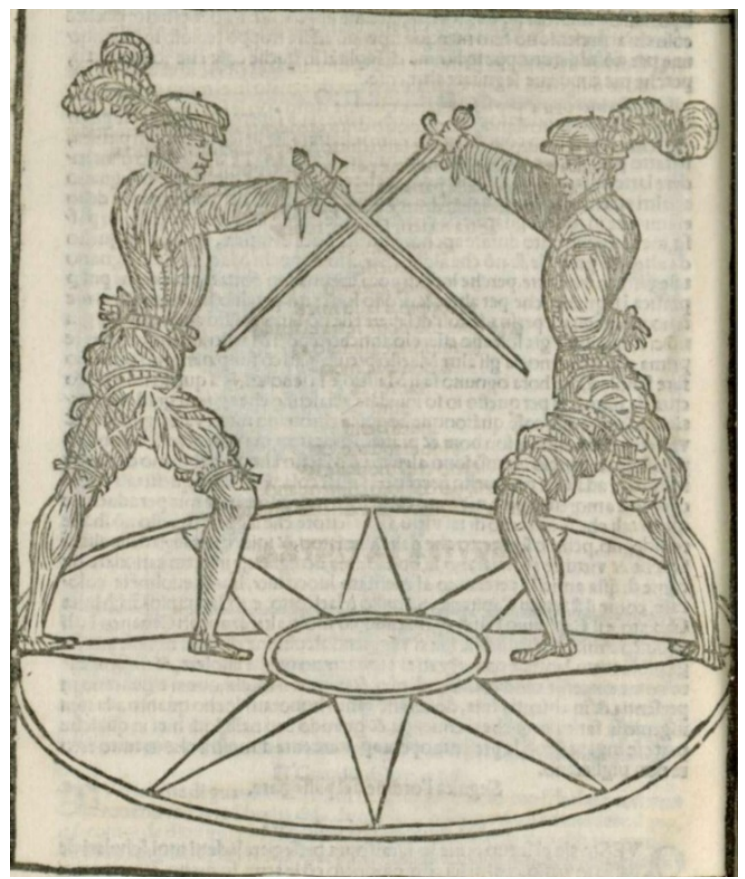

Figure 4: Achille Marzzo, Opera Nova, 2nd book, fol. 47v (Munich, Bayerische Staatsbibliothek, Res/4 Gymn. 26). Reproduced with permission. 


\section{II.3. Table of contents}

The manuscript offers a very clear and coherently organised structure which is confirmed by the exceptional presence of a register mixing, according to current definitions, a table of contents and alphabetical index at the end of the volume. I write 'exceptional' because to my knowledge this is a feature absent from most printed fight books, but I have found it in other forms in some chancery volumes, such as those of the city of Strasbourg. It should be noted that Meyer did not repeat this effort in his other works.

In the table below, I give in the left-hand column the foliation observed from the digital copy provided by the museum. I have set aside the flyleaf, assigning it the number 0 to start with the first folio with content. The manuscript itself has an internal numbering system, the imperfections of which have been discussed above, which I represent in the second column. In the third column, the main subject is roughly named in the absence of a more precise study of the content. For example, I have not separated the single rapier from the rapier and dagger, nor have I attempted to distinguish a separate section for the pike versus halberd opposition at the end of the section on the pike. Finally, the fourth column gives an account of the number of illustrations appearing in the chapters, knowing that the dedication contains only the coat of arms of the Veldenz counts, and the section on the two-handed sword contains a probably general part with a diagram of a sword and a divided man. All other illustrations are in colour, and in the case of the illustrations in the long pike section, are spread over the two facing pages; for calculating the total, the illustrations in the pike section spanning two pages are counted as one occurrence each, regardless of the number of folios over which the illustration may extend.

\begin{tabular}{|c|l|l|l|}
\hline Folio & Numbering & Content & Images \\
\hline $0^{r}-0^{v}$ & - & Flyleaf & \\
\hline $1^{r}-3^{v}$ & - & Dedication & 1 \\
\hline $44^{r}-24^{v}$ & $1-21$ & Two-handed sword & 9 \\
\hline $25^{r}-51^{r}$ & $22-48$ & Dussack & 23 \\
\hline $51^{r}-71^{v}$ & $48-66$ & Rapier & 18 \\
\hline $72^{r}-80^{v}$ & $67-75$ & Dagger & 6 \\
\hline $81^{r}-85^{r}$ & $78 ?-82$ & Staff & 3 \\
\hline $85^{v}-91^{v}$ & $82-88$ & Halberd & 6 \\
\hline $92^{r}-103^{v}$ & $89-100$ & Long pike & 10 \\
\hline $104 r-115^{v}$ & $101-112$ & Armoured combat & 3 \\
\hline $113^{r}-118^{v}$ & - & Index and table of contents & \\
\hline $119^{r}-119^{v}$ & - & Flyleaf & \\
\hline
\end{tabular}

Table 1: Table of content of the 1561 manuscript.

\section{PERSPECTIVES - DESIDERATA FOR FURTHER RESEARCH}

The rediscovery of this manuscript opens up a number of axes for further research. Firstly, as previously mentioned, it seems indispensable to have a codicological study to 
shed light on the stages of its creation and to understand the origin of the anomalies in the internal numbering of the manuscript. At first glance, the manuscript seems to have been written in at least two different hands, like the one preserved in Lund. The Rostock manuscript appears to be more composite, but should probably also contain parts of Joachim Meyer's autograph. The availability of these three manuscripts should make it possible to carry out a stylistic study and thus to verify the hypothesis that each of these manuscripts was at least partly written by the same hand, which could be assumed to be that of Meyer. ${ }^{17}$

The drawings in the Lund manuscript seem to be related to the engravings in the printed book, and thus attributable to Tobias Stimmer. The drawings in the rediscovered manuscript are clearly by another artist, given the undeniable differences in the characteristics of their artwork, especially in the exuberance of the clothing. The stylistic study could allow us to identify the author of these paintings, but on the other hand I have already mentioned the resemblance of some illustrations in the rapier section to the book of Achille Marozzo, so a wider comparative study between these two sources also seems necessary.

The dating of this manuscript, which is indisputable, also opens up a very interesting perspective on Joachim Meyer's work as a whole. Indeed, the Lund or Rostock manuscripts have often been identified, wrongly it seems to me, as preliminary works to the printed work. ${ }^{18}$ Having a second coherent manuscript, with a much wider scope of weapons than that of Lund, offers the pleasing prospect of a beautiful study on the textual history of the art of combat thought and composed by Joachim Meyer.

This manuscript should also help to clarify the purpose of such a document; it clearly appears to have been composed over several periods, with a dedication and an index added later, but even the technical texts seem to have been produced after the illustrations were made. The whole manuscript gives the impression of a high quality, self-sufficient piece of finished work, well and truly worthy of being dedicated to a Rhenish prince for the advancement of its author, and probably in the hope of offering him a good career later on. In any case, it seems to me that one should stop seeing Meyer's manuscripts as intermediate works, as this appears to be in no way consistent with the quality of the manuscripts, and even less compatible with their status as dedicated works.

\footnotetext{
17 A digital edition of the three manuscripts is ongoing at the University of Strasbourg (Guillaume Porte and Olivier Dupuis). Furthermore, the proceedings of the conference held at the University of Strasburg in 2021 for the $450^{\text {th }}$ commemoration of the death of the master will be published in the journal Sources (2022, as a special volume edited by Olivier Dupuis, Daniel Jaquet, and Guillaume Porte).

18 Jaquet, 'Combattre en Armure', vol. 1, pp. 60 and 66; Chaize, 'Les Arts martiaux de l'Occident médiéval’, p. 264.
} 
Finally, this manuscript does not seem to provide much additional biographical information on what is already known about Joachim Meyer. If the supposed date of birth for Joachim Meyer is correct, however, this dedicated work was produced when the author was barely twenty-four years old. This seems almost implausible nowadays. But if we look closely, it is six years older than the age of the young prince to whom he dedicated the manuscript, Georg Hans of Veldenz, who had already travelled to two royal courts. This young prince was to embark on extensive projects for the county of Lützelstein from 1568 , also at the age of twenty-five, including the creation of the city of the Counts Palatine, Phalsbourg, from scratch. Is it thus possible to conclude that such a young work is only an illustration of the adage, composed by the French playwright Corneille in 1636, that 'in souls nobly born valour does not depend upon age'? 19

\section{APPENDIX}

Staatsarchiv Basel, Universitätsarchiv K 7 fol. 107.

9/11/1558 Jakob Meyger, der Papierer und Bürger zu Basel und seine Frau Anna Fründt bekennen mit genannten Bürgen, dass sie dem Meister Michel Gernnler, als dem Vogt der Frau Mergelin Höfflin, Wittwe des Ludy Gernlers, einen jährlichen Zins von $2 \mathrm{fl}$. von ihrem Hause und Garten in der St. Albanvorstadt sowie von einer 1/2 Jucharten Reben vor dem St. Albantor um die Summe von 40 fl. verkauft haben.

Archives de la Ville et de la communauté urbaine de Strasbourg 1R23 484r , Saturday, 14 February, 1560. Request for authorisation to organise a Fechtschule by Joachim Meyer for the granting of the title of Freifechter of a person present at his side at the time of the request, but remaining anonymous.

Joachim Meier burger alhie, freifechter, er hett einen so neben ime gestanden gelert unnd [irer?] willens denselben wie der brach uff offner schul zufreyen und frey fechter zumachen, bitt ime zu under schiedlichen malen schul zuhalten zuzulassen.

Archives de la Ville et de la communauté urbaine de Strasbourg 1R24 57 ${ }^{\mathrm{r}}$, Saturday, 15 February, 1561. Two authorisations for Fechtscbulen requested jointly by Joachim Meyer and Christof Elias, the latter indicating that he was a pupil of the former.

Joachim Meier burger alhie bittet ime zuvergonnen ein fechttschul zuhalten desgleichen bittet Christoff Elias derso von ime Joachim meiern gelert ime uber acht tag hernacher gleicher gestelt ein schul zuhalten. Erkannt inen beiden iren geberen zulassen doch sagenn $\mathrm{d} z$ sye fursehung thun $\mathrm{d} z$ ordenlich gefochten und kein Unlust furgehe.

${ }^{19}$ Le Cid, act $2^{\text {nd }}$ scene II. Translation https://www.gutenberg.org/files/14954/14954-h/14954$\underline{\text { h.htm }}$ 
Archives de la Ville et de la communauté urbaine de Strasbourg 1R26 459v, Saturday, 30 October, 1563. Authorisation to organise a Fechtschule, requested by Wygand Brack, for the award of the title of Freifechter by 'Joachim the cutler', presumably Joachim Meyer.

Weigand Pranck es willt ime Johim der messerschmidt und fechtmeister begert zur einer freifechter machen bitt derwegen ime bitz montag ein schul zuvergonnen. Erkant und ist ime zugelassen

\section{BIBLIOGRAPHY}

\section{V.1. Primary sources}

de Narváez, Luis Pacheco, Nueva ciencia, y filosofia de la destreza de las armas, su teorica, y practica (Madrid: Melchor Sanchez, 1672)

Joacbim Meyer 1600: Transkription des Fechtbuchs 'Gründtliche Bescbreibung der freyen Ritterlichen und Adelichen kunst des Fechtens', ed. by Wolfgang Landwehr (Herne: VS-Books, 2018)

Lund, Universitetsbiblioteket, A. $4^{\circ} .2$ (Joachim Meyer, Gründtliche Beschreibung des Fechtens) $<$ http://urn.kb.se/resolve?urn=urn:nbn:se:alvin:portal:record-76351> [accessed 22 February 2021]

Marozzo, Achille, Opera Nova (Modena: Antonio Bergolae, 1536)

Meyer, Joachim Gründtliche Beschreibung der freyen Ritterlichen vnnd Adelichen kunst des Fechtens in allerley gebreuchlichen Webren mit vil schoenen und nuetzlichen Figuren gezieret vnd fuergestellet (Strasbourg: Thiebolt Berger, 1570) (examined copy: München, BSB, VD16 M5087)

— Gründtliche Beschreibung der freyen Ritterlichen und Adelichen kunst des Fechtens in allerley gebreucblichen Webren mit schoenen und nuetzlichen Figuren gezieret unnd fuergestellet (Augsbourg: Michael Manger, 1600) (examined copy: München, BSB, VD16 M5088)

Munich, Bayerisches Nationalmuseum, Bibl. 2465 (Joachim Meyer, Fechtbuch)

Munich, Bayerische Staatsbibliothek, Cod. icon. 393 (Paulus Hector Mair, Opus Amplissimum der Arte Athletica) < urn:nbn:de:bvb:12-bsb00006570-7> [accessed 18 March 2021]

Rostock, Universitätsbibliothek, Mss. var. 82 (Joachim Meyer, Fechtbuch von allerband geschwinden Stuckenn zu Ross und zu Fuß vnd zum Kampff <http:// purl.unirostock.de/rosdok/ppn780606825> [accessed 23 February 2021]

\section{V.2. Secondary literature}

Brioist, Pascal, Hervé Drévillon, and Pierre Serna, Croiser le fer, violence et culture de l'épée dans la France Moderne (XVIe-XVIIIe siècle) (Seyssel: Champ Vallon, 2002)

Chaize, Pierre-Alexandre, 'Les arts martiaux de l'Occident médiéval: comment s'écrit et se transmet un savoir gestuel à la fin du Moyen-Age' (unpublished doctoral thesis, University of Paris-Saclay, 2016) 
Das bayerische Nationalmuseum (München, 1868)

Dupuis Olivier, 'Joachim Meyer, escrimeur libre, bourgeois de Strasbourg (1537? 1571)', in Maîtres es techniques de combat à la fin du Moyen Âge et au début de la Renaissance, ed. by Fabrice Cognot (Dijon: AEDEH, 2006), pp. 107-20

'Joachim Meyer, free fencer, citizen of Strassburg (1537?-1571)' [trans. by J.L. Forgeng], in Jeffrey L. Forgeng, The Art of Sword Combat: A 1568 German Treatise on Swordmanship (London: Front Line, 2016), pp. 171-90

Forgeng, Jeffrey L., The Art of Sword Combat: A 1568 German Treatise on Swordmanship (London: Front Line, 2016)

Fuchs, Peter, 'Georg Johann I. der Scharfsinnige', in Neue Deutsche Biographie, vol. 6 (Berlin: Duncker \& Humblot, 1964), pp. 221-23

Führer durch das bayerische Nationalmusuem (Munich: Bayerische Nationalsmuseum, 1901)

Fübrer durch das Königlich bayerische nationalmuseum in München, 6th ed. (Munich:

Akademische Buchdruckerei F. Straub, 1887)

Jaquet, Daniel, 'Combattre en armure à la fin du Moyen Âge et au début de la

Renaissance d'après les livres de combat' (unpublished doctoral thesis, University of Genève, 2013)

Hefner-Alteneck, Jakob Heinrich von, Trachten, Kunstwerke und Gerätschaften vom frühen Mittelalter bis Ende des 18. Jabrbunderts, vol. 7 (Francfort: Keller, 1886)

Kittel Paul, George Jean (1543-1592) - Par la grâce de Dieu, Comte Palatin du Rhin, Duc de Bavière, Comte de Veldenz et de la Petite-Pierre, Fondateur de Phalsbourg, 27 septembre 1570 (Phalsbourg: Édition du musée de Phalsbourg, 2002)

Kleinau, Jens-Peter, '1561 Joachim Meyer dedicated a fencing book to the pfalzgrafen of Pfalz Veldenz' < https://talhoffer.wordpress.com/2011/07/04/1561-joachimmeyer-dedicated-a-fencing-book-to-the-pfalzgrafen-of-pfalz-veldenz-2/> [accessed 22 February 2021]

Lübeck, Wilhelm, Lehr- und Handbuch der deutschen Fechtleunst (Francfort an der Oder: Gustav Harnecker, 1865)

Mayer, Joseph Aloys, Katalog der Büchersammlung (Munich: Rieger'sche Universitätbuchhandlung, 1887)

Merkel, Johannes, Heinrich Husanus (1536 bis 1587), Herzoglich Sächsischer Rath, Mecklenburgischer Kanzler, Lüneburgischer Syndicus, eine Lebenscbilderung (Göttingen: Lüder Horstmann, 1898)

Murray, John, Handbook for Travellers in Southern Germany, 12th ed. (London, 1873)

Pylkkänen, Riitta, Säätyläispuku Suomessa V anhemmalla Vaasa-ajalla 1550-1620 (Helsinki: Suomen Muinaismuistoyhdistys, 1956)

Weniger, Matthias, 'Die Büchersammlung des Bayerischen Nationalmuseums und die Bibliothek des Martin Joseph von Reider', Müncher Jabrbuch der Bildenden Kunst, 17 (2012), 203-50 